\title{
Development of citrus fruit fly control strategies for small-holders in Nigeria
}

\author{
Vincent C. UMEH ${ }^{a *}$, Abayomi A. OLANIYAN ${ }^{a}$, James KER ${ }^{b}$, Joseph ANDIR
}

a National Horticultural Research Institute, PMB 5432 Idi-Ishin, Jericho reservation area, Ibadan, Nigeria emnumea@skannet.com

${ }^{\mathrm{b}}$ Benue State Agricultural and Rural Development Authority, Makurdi, Nigeria
* Correspondence and reprints

Received 1 October 2003 Accepted 4 May 2004

Fruits, 2004, vol. 59, p. 265-274 (C) $2004 \mathrm{Cirad} /$ EDP Sciences All rights reserved DOI: $10.1051 /$ fruits:2004025

RESUMEN EsPAÑOL, p. 274

\section{Development of citrus fruit fly control strategies for small-holders in Nigeria.}

Abstract - Introduction. Damage of citrus fruits by the Mediterranean fruit fly Ceratitis capitata Weid. results in economic losses in Nigeria. The majority of the citrus producers are smallholders who are yet to adopt standard citrus production practices. A trial was therefore established in a savannah zone of Nigeria with a Southern Guinea agroecology to evaluate simple fruit fly control practices. Materials and methods. The efficacy of combining cultural practices such as removal of dropped fruits, changes of harvest period, and three applications of dimethoate/cypermethrine mixture in controlling fruit fly damage was tested on sweet orange Citrus sinensis (L.) Osbeck var. Valencia Late in 2000 and 2001. Results. Fruits attacked by C. capitata increased with fruit maturity and were positively correlated with the number of dropped fruits. Insecticide applications and removal of dropped fruits significantly reduced the number of fruits attacked by the fruit flies. Similarly, early harvesting at 50\% fruit ripening significantly $(P<0.05)$ reduced the number of fruits attacked by the fruit flies when compared with the late harvesting at $90 \%$ ripening. The interactive effects of insecticide applications and the period of harvest significantly $(P<0.05)$ reduced attacks on fruits. Discussions. Judicious use of insecticides, periods of harvest and removal of fallen fruits reduce fruit fly damage. Late harvest and non-removal of fallen fruits constitute fruit fly reservoirs for the re-infestation of other clean fruits. Since the tested control methods were simple, they can be adopted by small-holders for the control of fruit flies.

Nigeria / Citrus / insect control / integrated control / Ceratitis capitata / insecticides / cultivation

\section{Développement des méthodes de lutte contre la mouche des agrumes pour les petits cultivateurs au Nigéria.}

Résumé - Introduction. Les dégâts causés aux agrumes par la mouche des fruits Ceratitis capitata Weid. causent de fortes pertes économiques au Nigeria. La plupart des producteurs d'agrumes sont de petits producteurs qui n'utilisent pas encore de techniques de production appropriées. Pour cette raison, des essais ont été établis pour évaluer des méthodes de lutte simples contre la mouche des fruits dans la savane d'une zone du Nigeria ayant une écologie sudguinéenne. Matériel et méthodes. L'efficacité de la combinaison de pratiques culturales, telles que le ramassage des fruits tombés, la modification de la période de récolte et l'application d'un mélange de diméthoate/cyperméthrine, contre les dégâts de mouches des fruits sur oranges Citrus sinensis (L.) Osbeck var. Valencia Late a été évaluée en 2000 et 2001. Résultats. Le nombre de fruits attaqués par $C$. capitata a augmenté avec la maturation des fruits et il a été positivement corrélé aux nombres de fruits tombés. Les traitements insecticides et l'élimination des fruits tombés ont significativement réduit le nombre de fruits attaqués par les mouches. De la même façon, une récolte précoce de fruits mûrs à $50 \%$ a significativement $(P<0.05)$ réduit le nombre de fruits attaqués par les mouches par rapport à la récolte tardive portant sur des fruits mûrs à $90 \%$. Les effets interactifs entre les traitements insecticides et la période de récolte ont significativement $(P<0.05)$ réduit le nombre de fruits attaqués. Discussion. L'utilisation judicieuse des insecticides, une récolte faite au bon stade de maturation et l'élimination des fruits tombés ont réduit les dégâts de la mouche des fruits. Une récolte tardive et des fruits laissés à terre constituent des réservoirs à partir desquels des fruits sains peuvent être infestés. La simplicité des méthodes de lutte testées permet de les proposer aux petits producteurs d'agrumes pour lutter contre la mouche des fruits.

Nigeria / Citrus / lutte anti-insecte / lutte intégrée / Ceratitis capitata / insecticide / pratique culturale 


\section{Introduction}

Citrus is the most widely grown fruit crop in Nigeria [1]. However, pests and diseases are identified as major limiting factors to its production. While some insect pests are noted to contribute to citrus decline, some play a major role in reducing fruit yields and rendering them unacceptable in the market. Fruit flies and fruit piercing moths are known as the most important fruit insect pests in Nigeria, causing fruit damage and premature fruit drops [2]. These insects contribute significantly to yield losses. The extent of fruit fly damage is believed to be associated with the degree of ripeness of the fruits [3] and local enhancement by conspecifics [4]. Observations have shown that, in most parts of Nigeria, fruit fly damage occurs at all times when fruits are set, whereas damage by the fruit piercing moths varies from one year to another (Umeh, unpublished data). Fruit fly populations can be said to have attained a numerical stability over a long period [5] and are of economic significance at a particular phenological stage of the plant (usually during the fruiting season). Female flies pierce fruits to lay their eggs. The emerging larvae then feed on fruit pulp, thus rendering the latter undesirable [2]. In severe infestation, as high as $70 \%$ of set fruits may be lost with the combined attack of these insects [6]. Late harvest allows some fruits to over-ripen, increasing their sugar content [7] and, therefore, the fruits become most attractive to flies. They thus constitute reservoirs of fruit flies from which other fruits are attacked. Furthermore, the stage of fruit ripeness is linked to its physicochemical characteristics, i.e., at a certain mineral content level, they are most attractive to fruit flies for oviposition. These characteristics include the level of essential oils in the fruit rind and the reduction of acidity of the fruit rind and juice [3, 7] that increases with increasing fruit ripening.

Neglecting the development of necessary interventions to this constraint may lead to considerable decline in citrus production in Nigeria. Most often, farmers embark on the control of insects using inappropriate chemical pesticides or wrong dosages and, thus, do not achieve their desired goals. Excessive use of chemical sprays is presently being discouraged due to their adverse impact on the environment (including human health hazards and the elimination of beneficial parasites and predators). Instead, selective environmentally safe chemicals and protein hydrolysates $[8,9]$ are used in baits with pheromone traps to reduce fruit fly populations to below the economic threshold. Other preferable alternatives to chemicals for fruit fly control include the use of entomopathogenic microorganisms such as Metarbizium anisopliae [10]. The potential of the use of parasitoids in the biological control of fruit flies has been evaluated by many authors; they were found to be promising even with some environmentally friendly insecticides as part of Integrated Pest Management (IPM) strategies [11-13]. The dynamic equilibrium between pests and their natural enemies on the one hand, and between them and their host environments on the other hand, contributes to the characteristics of the species population. There is therefore the need to investigate the appropriate control measures for citrus fruit-damaging insects without adversely upsetting this existing natural equilibrium. The majority of citrus producers in Nigeria are small-holders who have not adopted standard production practices either as a result of ignorance or due to meagre resources available to them. Therefore the proposed control measures must be relatively cheap and environmentally friendly to be adopted by these farmers.

The specific objective of our study was to evaluate the efficacy of combining the use of an insecticide mixture and some cultural methods such as the timing of harvest periods and the removal of dropped fruits for controlling citrus fruit flies on sweet orange Citrus sinensis (L.) Osbeck. The study was undertaken with a view to recommending to producers cheap and environmentally safe control practices as part of an IPM package. 


\section{Materials and methods}

\subsection{Site and varietal selection for the trial}

Two 15-year-old farmers' orchards in a village (long. $8^{\circ} 18^{\prime} \mathrm{E}$ and lat. $7^{\circ} 20^{\prime} \mathrm{N}$ ) in the outskirts of Gboko town (Benue State, Nigeria) were used to superimpose the fruit fly control treatments in July 2000 and 2001. The Gboko area, which is in the middle belt of Nigeria, was chosen for the trials based on its premier position in citrus production and the importance of the crop in the socio-economic life of the inhabitants.

During each trial year, two orchards were selected for trial: one where dropped fruits were to be picked and another where the dropped fruits were not to be picked. The two orchards were separated from each other by approximately $120 \mathrm{~m}$.

The choice of sites was based on criteria for on-farm researcher-managed experimentation $[14,15]$. The citrus groves were made up of three sweet orange varieties widely grown in Benue state, namely, Valencia late, Washington Navel and Ibadan Sweet. The trees were spaced $6 \mathrm{~m}$ apart. Each variety was grouped in a separate portion of the orchards. However, portions of the orchards with Valencia Late budded on Rough Lemon were used for the trials because only the latter had fruits at a tender stage $(5 \mathrm{~cm}$ diameter) suitable for initiating the trial. Other varieties had scanty fruits or were yet to fruit. The average height of the trees was $2.5 \mathrm{~m}$, while the diameter of the middle portion of the canopy was approximately $2.2 \mathrm{~m}$.

\subsection{Field layout and treatment applications}

The experimental layout was a 'criss-cross', which is a modified split-plot design [15, 16], adopted because the application of removal and non-removal of dropped fruits in separate orchards constituted the main plots. The treatments applied were the following:

- removal and non-removal of dropped fruits at the two separate sites (orchards), respectively (main plot),
- insecticide application of a mixture of $5 \mathrm{~mL}$ cypermethrine $+5 \mathrm{~mL}$ dimethoate in $20 \mathrm{~L}$ of water and the control treatment (subplot),

- two harvest regimes, i.e., early harvest at $50 \%$ fruit ripening and late harvest when $90 \%$ of the fruits were ripe (sub-subplot).

Randomisation was therefore effected at split-plot and split split-plot levels. The factorial trials were established after being modified according to the treatments to be tested as described above. Treatments were replicated four times per site. The cover spray (insecticide mixture) was applied monthly as foliar application from July-October, giving about 21 days' interval between the last application and the first harvest. To reduce any probable attack by fruit-piercing moths that usually visit the orchard at dusk, application of insecticide was usually started between 5.30 and 6 p.m. in the evenings. A total of four applications was made using a knapsack sprayer with a nozzle that discharges long-distance spray jets. A twentylitre spray load was applied to each set of 10 trees. This number of insecticide applications was in contrast to the earlier practice recommended for farmers to apply insecticides every 14 days from early fruiting to maturity [5, 17]

Trees earmarked for the study were randomly sampled and labelled for continuous monitoring. Each tree was regarded as a sampling unit and was divided into upper and lower canopy (within a clear visible limit). Four trees were sampled per treatment. Observation of fruits for damage studies and counting of dropped fruits were done every 14 days on each of the randomly selected trees. Two fruits in each of five points along the circumference of the two portions were sampled and examined for damage in each tree. Infestation levels were thus scored from 10 points or 20 fruits. For the verification of the lethal effect of insecticides on predominant natural enemies, assessment of changes in the population of commonly encountered ladybird (Coleoptera) predators of aphids was made three times at the early, middle and harvest stages of the trials. Orchard owners participated in the removal of dropped fruits at 2-week intervals until harvest, at the site designated 
Figure 1.

Progression in the number of fruits attacked by Ceratitis capitata in relation to fruit maturity and the removal of dropped fruits in 2000 and 2001, for citrus not treated against Ceratitis capitata.

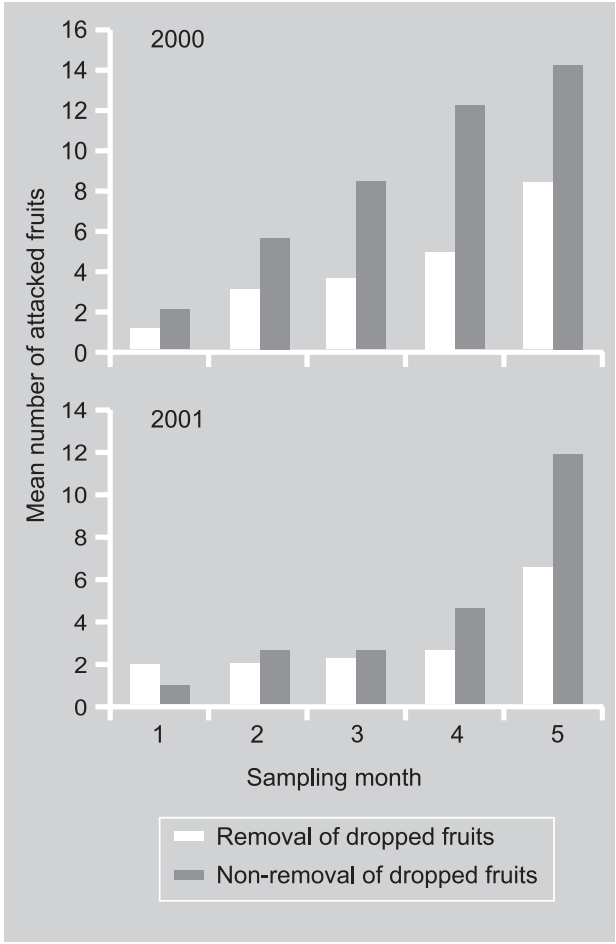

for fruit removal. At this site, records of the number of dropped fruits were taken before fruits were discarded by deep burying. The percentage of ripe fruits was calculated by counting ripe fruits from 10 sampling points, i.e., 20 fruits.

Immature stages of fruit fly observed during sampling were raised to adulthood by retaining them in the infested fruits placed in $(0.4 \times 0.6 \times 0.6) \mathrm{m}$ cages. Each cage was covered at the sides by wire gauze, at the top by glass and at the base by sand-covered plywood. Emerging adults were captured and identified in the laboratory using identification keys [18].

\subsection{Statistical analyses}

In the fields earmarked for non-removal of dropped fruits, the number of dropped fruits at each sampling date was assessed cumulatively and was later recalculated for actual dropped fruits per treatment by the subtraction of previous numbers from the subsequent ones. Data on fruit fly damage levels and number of beetles (natural enemy) were transformed using square root transformation $(X+0.5)$. Analysis of variance (ANOVA) was conducted on each set of data. The effect of each factor was tested against its own error term. The interactions between the treatments on mean number of attacked or dropped fruits were tested against the error terms corresponding to the individual treatments (i.e., removal and non-removal of fruits, insecticide application and harvest regimes). All statistical analyses were computed with the Statistical Analysis System [19]. Means of significantly different tests were separated using Duncan's New Multiple Range Test [20]. Correlation analyses were conducted to determine the relationship between the number of attacked fruits and those that dropped beneath the trees. Unless otherwise stated, all statistical tests were judged significant at $P=0.05$.

\section{Results}

Fruits of Valencia Late were observed to be attacked by the fruit fly Ceratitis capitata Weid. During the study, attack by the fruit piercing moth Achaea linardi was negligible. Therefore data is not presented on the fruit piercing moth.

In 2000 and 2001, the mean number of fruits attacked by the fruit flies on the nontreated trees increased progressively with time from the first month of sampling to harvest, i.e., fruit maturity (figure 1). These increases were even higher in the site where dropped fruits were not picked than in that where they were removed and buried. The percentages of fruits that were attacked by fruit flies varied between ( 5 and 70$) \%$ and ( 5 and 60$) \%$, respectively, in the 2000 and 2001 sampling periods. Greater damage was recorded in 2000 than in 2001.

Analysis of variance showed that the number of fruits attacked by fruit flies and that dropped under the trees were significantly $(P<0.01)$ different with respect to the various treatments. Insecticide applications significantly $(P<0.001)$ decreased both the number of fruits attacked by the flies and the number of dropped ones due to attack. In 

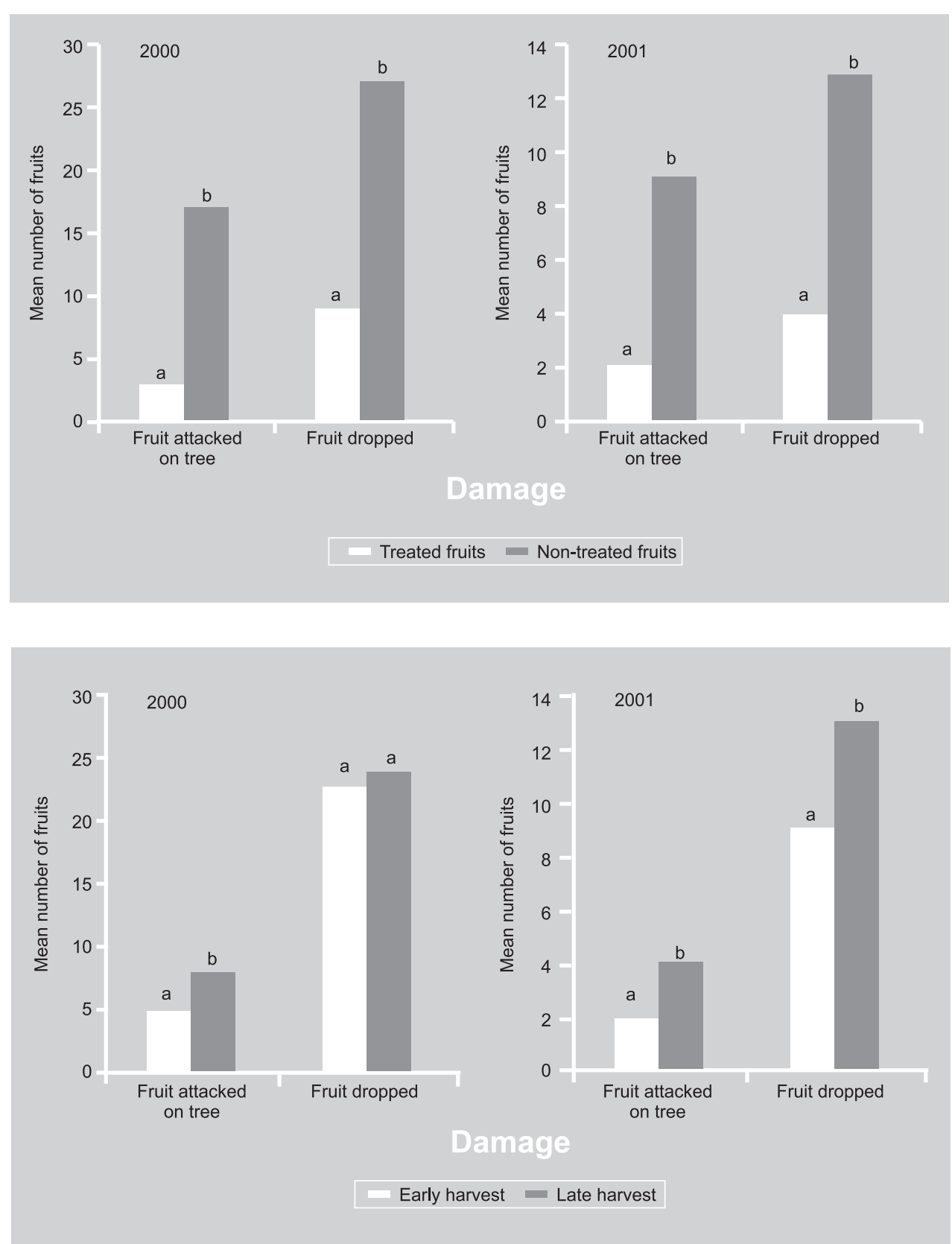

2000, a mean of three and ten fruits, respectively, was attacked by fruit flies in treated and non-treated stands (figure 2). In 2001, however, treated stands still had a lower number of attacked fruits than the untreated ones with two fruits compared with four, respectively, although the number of attacked fruits was relatively lower than that of the previous year.
Figure 2.

Effects of insecticide treatments on Ceratitis capitata damage of citrus fruits (Benue State, Nigeria).

Figure 3.

Effects of the harvest period on Ceratitis capitata damage of citrus fruits in Benue State, Nigeria. 
Figure 4.

Effects of the removal of dropped fruits on Ceratitis capitata damage of citrus fruits in Benue State, Nigeria.

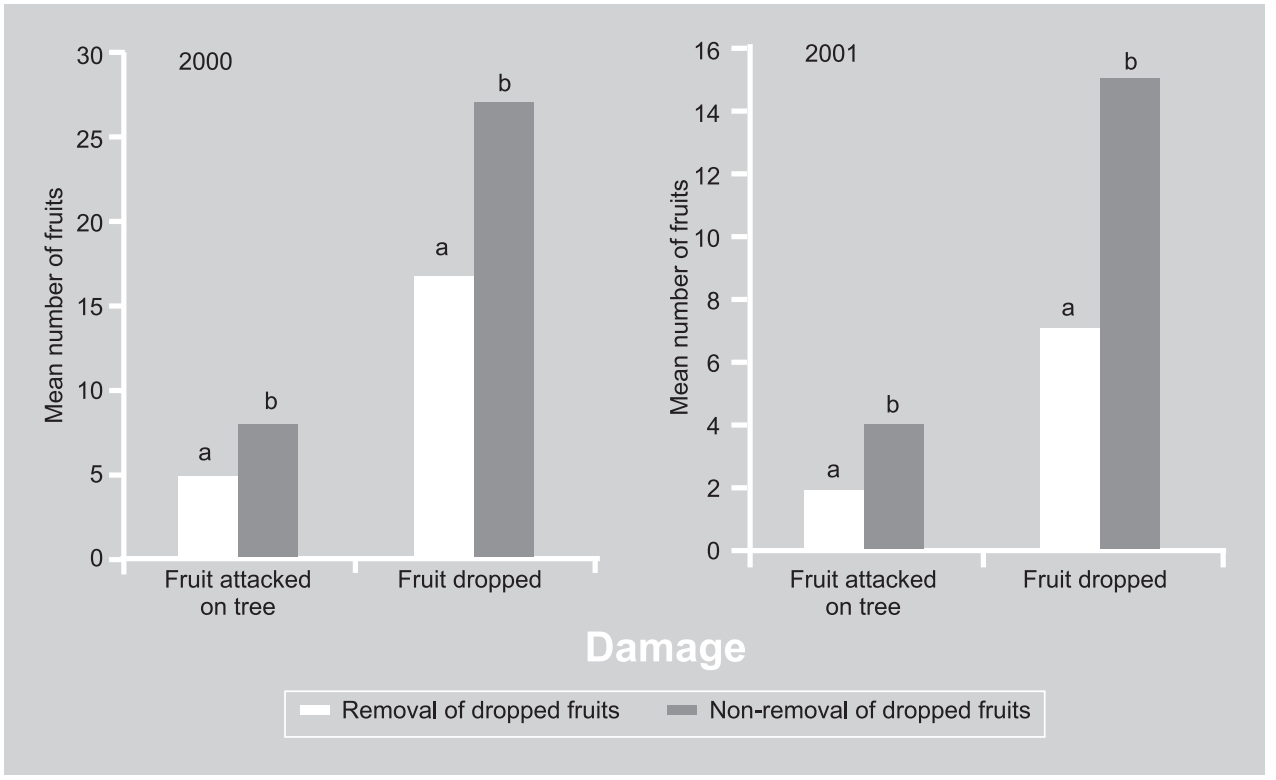

attacked on the trees and those that dropped beneath the trees.

Similarly, removal of dropped fruits significantly $(P<0.01)$ reduced the number of fruits attacked by C. capitata on the trees in 2000 and 2001 (figure 4). The interactive effects of insecticide applications and the period of harvest significantly reduced fruit fly attacks on fruits in both years.

Other treatment interactions did not significantly $(P>0.05)$ reduce the number of fruits attacked by the flies or those that dropped beneath the trees (table I). A significantly high positive correlation was observed between the numbers of dropped and attacked fruits in $2000(r=0.80 ; P<$ $0.001 ; n=24)$. However, the correlation coefficient obtained between these parameters in 2001 was low $(r=0.36 ; P<0.05 ; n=24)$.

A maximum mean of three beetles (predators) Scymnus sp. was observed per tree. However, there was no significant $(P>0.05)$ difference between the mean populations of this predator on the trees treated with the insecticide mixture and those untreated in $2000(1.3 \pm 1.0$ insects and $1.2 \pm 0.9$, respectively). Similarly, no significant $(P>0.05)$ difference was observed between the mean populations of Scymnus sp. in the treated and untreated citrus trees in $2001(1.6 \pm 0.9$ and $1.8 \pm 0.9$, respectively). The populations of Scymnus sp. did not fluctuate much during the study period irrespective of insecticidal treatments (figure 5).

\section{Discussions}

The number of damaged citrus fruits on the treated trees was significantly low whatever the period of harvest or the removal of the dropped fruits; thus, three applications of dimethoate mixed with cypermethrin was effective in reducing fruit fly damage in both the 2000 and 2001 trials. Other organophosphate insecticides such as malathion, fenthion or deltamethrin singly or in mixtures with attractants and oils have been reported as being effective for the control of fruit flies $[3,21,22]$. In our studies, the choice of insecticides tested was partly based on their ready availability in most pesticide shops in Nigeria. However, the success of any insecticidal control depends on the right choice of insecticide, accurate utilisation of dosages, the period of initiation of control and the sustainability of applications. Most of these precautions are not observed by majority of farmers when insecticides are used, thereby resulting in control failures. 


\begin{tabular}{|c|c|c|c|c|c|}
\hline \multirow{3}{*}{ Treatment effects } & \multirow{3}{*}{ Degree of freedom } & \multicolumn{4}{|c|}{ F-values } \\
\hline & & \multicolumn{2}{|c|}{2000} & \multicolumn{2}{|c|}{2001} \\
\hline & & Attacked & Dropped & Attacked & Dropped \\
\hline \multicolumn{6}{|l|}{ Main plot effects } \\
\hline Replication & 3 & - & - & - & - \\
\hline Removal of fruits $(A)$ & 1 & $12.4^{*}$ & $73.3^{\star \star}$ & $12.6^{\star}$ & $19.4^{*}$ \\
\hline Error & 3 & - & - & - & - \\
\hline \multicolumn{6}{|l|}{ Subplot effects } \\
\hline $\begin{array}{l}\text { Insecticide } \\
\text { application (B) }\end{array}$ & 1 & $27.1^{\star \star \star}$ & $14.4^{\star \star \star}$ & $18.3^{\star \star \star}$ & $21.4^{\star \star \star}$ \\
\hline$A \times B$ & 1 & $0.7 \mathrm{~ns}$ & $0.6 \mathrm{~ns}$ & $0.3 \mathrm{~ns}$ & $2.8 \mathrm{~ns}$ \\
\hline Error & 6 & - & - & - & - \\
\hline \multicolumn{6}{|l|}{ Sub-subplot effect } \\
\hline Harvest regime $(C)$ & 1 & $6.4^{*}$ & $2.8 \mathrm{~ns}$ & $23.1^{\star}$ & $17.1^{\star}$ \\
\hline$A \times C$ & 1 & $0.9 \mathrm{~ns}$ & $1.3 \mathrm{~ns}$ & $1.1 \mathrm{~ns}$ & $0.2 \mathrm{~ns}$ \\
\hline $\mathrm{B} \times \mathrm{C}$ & 1 & $13.4^{\star}$ & $0.4 \mathrm{~ns}$ & $5.0^{*}$ & $0.5 \mathrm{~ns}$ \\
\hline$A \times B \times C$ & 1 & $0.5 \mathrm{~ns}$ & $0.1 \mathrm{~ns}$ & $1.1 \mathrm{~ns}$ & $0.3 \mathrm{~ns}$ \\
\hline Error & 12 & - & - & - & - \\
\hline
\end{tabular}

Furthermore, the majority of the farmers (mostly small-holders) do not possess the financial means to purchase these synthetic insecticides. The reduced number of insecticide applications and dosage tested in our trials saves costs compared with earlier recommendations in use against citrus fruit flies whereby insecticides are applied at 2-week intervals until harvest [5, 17]. It was also observed that the 2001 trial had less fruit damage than that of the 2000 one, probably due to the reduced fruit fly presence resulting from the residual effects of the treatments of 2000 since the same sites were used.

The increase in damaged fruits observed in the site where dropped fruits were not removed was due to the fruit fly infestation reservoir provided by such fruits for the reinfestation of other clean fruits. Similarly, fruit drop has been reported in another study to be correlated with the fruit fly infestation level [2]. Early harvesting reduced the number of fruits available for infestation by fruit insect pests. Umeh et al. [23] observed a positive relationship between the extent of ripeness

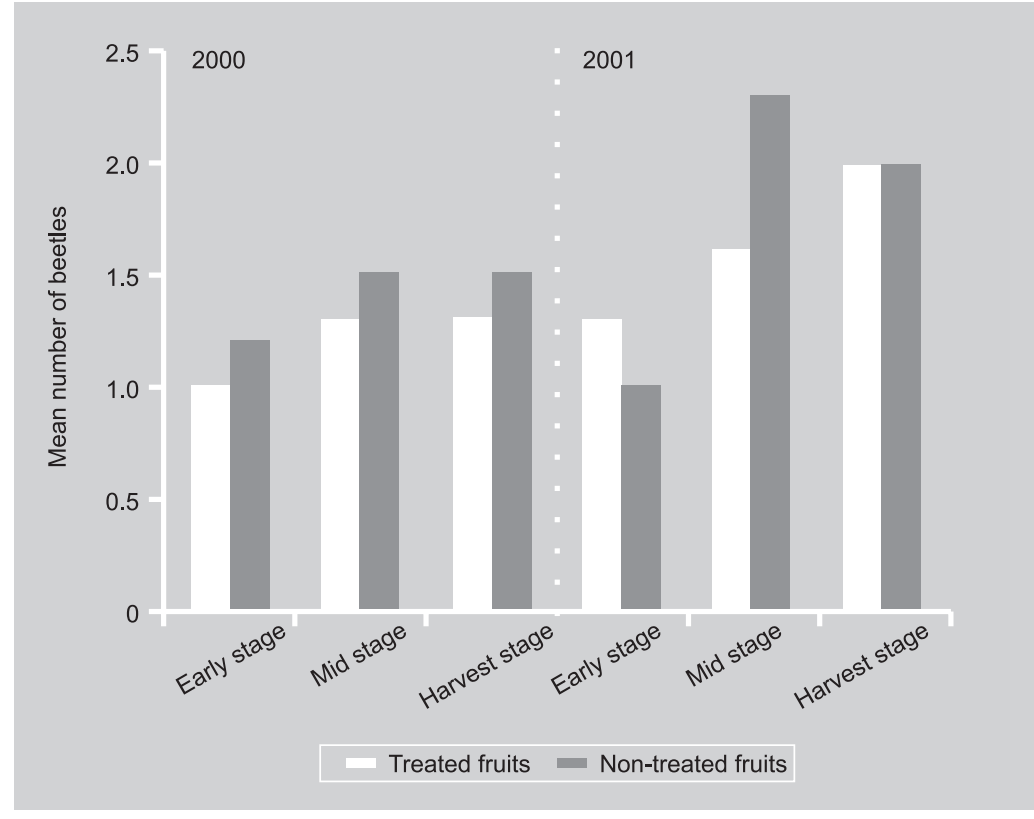

Figure 5.

of citrus fruits and their infestation by the Population of Scymnus sp. in a shield bug Leptoglosus membranaeceus Fab- Valencia sweet orange orchard ricius. It has also been reported elsewhere treated with insecticides in that fruit maturity and stage of ripeness affected Benue State, Nigeria. 
the infestation of fruits by C. capitata [24, 25]. The present study confirmed the latter findings since early initiation of harvesting at $50 \%$ of ripe fruits significantly reduced damage compared with when $90 \%$ of the fruits were allowed to ripen before harvesting. Although physicochemical analyses were not undertaken in the present study to determine levels of essential oils and acidity of the fruit rind due to ripeness, the results from the two categories of ripeness indicated the best affinity of C. capitata for 90\% of fruit ripening and, consequently, the resultant high damage. Our results (figure 1) also show how $C$. capitata attacks increased progressively with fruit maturity until harvest.

Attacks on fruits by fruit flies contributed significantly to fruit drop, although it is also believed that some of the dropped fruits may have been due to attack by the fruit piercing moth that also causes premature fruit drop. However, only a few occurrences of fruit piercing moths were observed during the period of this study. Nevertheless, the high contribution of the flies to fruit drop was shown by the high positive correlation between $C$. capitata-attacked fruits on trees and the number of dropped ones. Dropped fruits increase the incipient population of flies for the re-infestation of new mature fruits.

In the face of their present economic hardship, resource-poor citrus growers in Nigeria will have to rely mostly on the cultural control methods evaluated in the present study. Although synthetic pesticides may be indispensable in fruit fly-endemic areas (if funds are available to the concerned farmers), they are to be applied sparingly, i.e., using the tested effective minimal dosages. Application during the evening ( 6 p.m.) may have an additional effect of reducing the population of fruit piercing moths that usually visit the orchards at dusk.

The results of the present study therefore indicate that, in the interim, four applications of cypermethrine and dimethoate mixture with good cultural practices will minimise fruit damage by fruit flies. These recommended practices should include the removal of dropped host fruits and the choice of proper timing for harvests. These measures could increase yields for small-holder citrus farmers in Nigeria.

\section{Acknowledgements}

The authors thank the National Horticultural Research Institute (NIHORT) for providing the funds used in executing this project. They are also grateful to the Benue State Agricultural and Rural Development Authority (BNARDA) for their logistical support and to Dr. Henry Fadamiro for his contributions.

\section{References}

[1] Oyebanji O.O., Fruit crop programme of ADPs in southern Nigeria, Proc. Ntl. Workshop on fruit and vegetable seedling production, National Horticultural Research Institute (NIHORT), Idi-Ishin, Ibadan, Nigeria, 10-13 February, 1987.

[2] Umeh V.C., Ahonsi S., Kolade J.A., Insect pests encountered in a citrus orchard in Nigeria, Fruits 53 (6) (1998) 397-408.

[3] Dhouibi M.H., Gahbiche H., Saaidia B., Variations in Ceratitis capitata infestation of fruit according to fruit locations on the tree and orange ripeness, Fruits 50 (1) (1995) 39-49.

[4] Prokopy R.J., Miller N.W., Duan J.J., Vargas R.I., Local enhancement of arrivals of Ceratitis capitata females on fruit mimics, Entomol. Exp. Appl. 97 (2000) 211-217.

[5] Eguagie W.E., Udensi N., Control of insect pests and diseases of citrus and mango in Nigeria, National Horticultural Research Institute (NIHORT), Tech. Bull., No. 5, Nigeria, 1989.

[6] Babatola J.O., Diseases and pests of fruits and their control, in: Proc. Ntl. Fruit Production Workshop, FACU-NIHORT, Ibadan, Nigeria, 1985, pp. 120-132.

[7] Attaway A., Biochemistry of fruits and their products, Hulme A.C. (Ed), Acad. Press Lond., UK, 1971, pp. 107-161.

[8] Steiner L.F., Fruit fly control in Hawaii with poison bait sprays containing protein hydrolysates, J. Econ. Entomol. 45 (1952) 838-843.

[9] Chambers D.L., Dose-mortality test of malathion and boric acid exposed on leaves in the field. Monthly narrative, Nov., USDAAPHIS, Antigua, Guatemala, 1987. 
[10] Lezama-Gutiérrez R., Trujillo-de la Luz A., Molina-Ochoa J., Robolledo-Dominquez O., Pescador A.R., Lopez-Edwards M., Aluja M., Virulence of Metarhizium anisopliae (Deuteromycotina: Hyphomycetes) on Anastrepha ludens (Diptera: Tephritidae): laboratory and field trials, J. Econ. Entomol. 93 (4) (2000) 1080-1084.

[11] Purcell M.F., Contribution of biological control to integrated pest management of tephritid fruit flies in the tropics and subtropics, Integr. Pest Manage. Rev. 3 (1998) 63-83.

[12] Peck S.L., McQuate G.T., Field tests of environmentally friendly malathion replacements to suppress wild Mediterranean fruit fly (Diptera: Tephritidae) populations, J. Econ. Entomol. 93 (2000) 280-289.

[13] Vargas R.I., Peck S.L., McQuate G.T., Jackson C.G., Stark J.D., Armstrong J.W., Potential for areawide integrated management of Mediterranean fruit fly (Diptera: Tephritidae) with a braconid parasitoid and a novel bait spray, J. Econ. Entomol. 94 (4) (2001) 817-825

[14] Mutsaers H.J.W., Walker P., On-farm research in theory and practice, Intec Pinters Ltd., Ibadan, Nigeria, 1991.

[15] Mutsaers H.J.W., Weber G.K., Walker P., Fischer N.M., A field guide for on-farm experimentation, IITA/CTA/ ISNAR, Nigeria, 1997.

[16] Cochran W.G, Cox G.M., Experimental design, 2nd ed., John Wiley and Sons, Inc. New York, USA, 1992, pp. 305-309.

[17] Anonymous, Advances in fruit and vegetable research at NIHORT 1976-1986. A commemorative publication to mark the 10th Anniver- sary of the National Horticultural Research Institute (NIHORT), Ibadan, Nigeria, 1986, pp. $42-43$.

[18] White I.M., Elso-Harris M.M., Fruit flies of economic significance: their identification and bionomics, CABI, Wallingford, UK, 1992, $601 \mathrm{p}$.

[19] SAS Insitute., SAS user's guide: statistics 5th ed., SAS Institute, Carry, North Carolina, USA, 1985.

[20] Gomez K.A., Gomez A.A., Statistical procedures for agricultural research, 2nd ed., John Wiley and Sons, New York, USA, 1984, 680 p.

[21] Roessler Y., Insecticidal bait and cover sprays, in: fruit flies, their biology, natural enemies and control, Vol. 3B, Elsevier, 1989, pp. 329336.

[22] VincenotD., QuiliciS., Lutte raisonnéeen vergers d'agrumes à l'île de la Réunion : expérimentation et développement, Fruits 50 (1) (1995) 27-38.

[23] Umeh V.C., Ibekwe H.N., Amih C.A., Citrus damage by Leptoglosus membranaeceus fabricius (Hemiptera: Coreidae) in part of South Eastern Nigeria, in: Akpa A.D. (Ed.), Proc. 18th annu. Conf. Hortic. Soc. Nigeria, Inst. Agric. Res., Samaru, Ahmadu Bello Univ., Zaria, Nigeria, 2000, pp. 25-30.

[24] Noussourou M., Diarra B., Mouche des fruits au Mali : Biologie et possibilité de lutte intégrée, Sahel IPM 6 (1995) 2-13.

[25] Ortiz J.M., Tadeo J.L., Estelles A., Características físicoquímicas de 'Navelina', 'Washington Navel' y su evolución durante la maduración, Fruits 42 (1) (1987) 435-441. 


\section{Desarrollo de métodos de lucha contra la mosca de los cítricos para los pequeños campesinos en Nigeria.}

Resumen - Introducción. Los daños que provoca en los cítricos la mosca de la fruta Ceratitis capitata Weid. ocasionan importantes pérdidas económicas en Nigeria. La mayoría de los productores de cítricos son pequeños productores que aún no utilizan técnicas de producción adecuadas. Por esta razón, se establecieron unos ensayos para evaluar métodos de lucha simples contra la mosca de la fruta en la sabana de una zona de Nigeria de ecología sur-guineana. Material y métodos. En 2000 y 2001, se evaluó la eficacia de la combinación de prácticas de cultivo, como la recogida de la fruta caída, la modificación del período de cosecha y la aplicación de una mezcla de dimetoato/cipermetrina, contra los daños de moscas de la fruta en naranjas Citrus sinensis (L.) Osbeck var. Valencia Late. Resultados. El número de frutos atacados por $C$. capitata aumentó con la maduración de los frutos y presentaron una correlación positiva con el número de frutos caídos. Los tratamientos insecticidas y la eliminación de los frutos caídos redujeron significativamente el número de frutos atacados por las moscas. Igualmente, una cosecha precoz de frutos maduros al $50 \%$, redujo significativamente $(P<0.05)$ el número de frutos atacados por las moscas respecto de la cosecha tardía efectuada en frutos con un $90 \%$ de madurez. Los efectos interactivos entre los tratamientos insecticidas y el período de cosecha redujeron significativamente $(P<0.05)$ el número de frutos atacados. Discusión. La utilización razonable de los insecticidas, una cosecha hecha en el momento adecuado de maduración y la eliminación de los frutos caídos redujo los daños de la mosca de la fruta. Una cosecha tardía y la fruta dejada en el suelo constituyen reservorios contaminantes a partir de los cuales se pueden infectar los frutos sanos. La simplicidad de los métodos de lucha probados permite proponerlos a los pequeños productores de cítricos para combatir la mosca de la fruta.

Nigeria / Citrus / control de insectos / lucha integrada / Ceratitis capitata / insecticidas / cultivo

To access this journal online: www.edpsciences.org 